\title{
Resenha: Memes of Translation: The spread of ideas in translation theory
}

Monique Pfau*

Chesterman, Andrew. Memes of Translation: The spread of ideas in translation theory. J ohn Benjamins Publishing Company: Amsterdam/ Philadelphia, 1997.

Mesmo tendo sido publicada em 1997, há quase vinte anos, é possível perceber como a obra traz discussões que ainda são recorrentes entre os Estudos da Tradução tanto nas salas de aula como em eventos ou em críticas tradutórias. Chesterman aborda tendências de traduzir e de pensar tradução na história e no mundo contemporâneo através daquilo que ele chama de memes e compreende as teorias tradutórias como um processo de evolução.

Sua obra inicia-se a partir da conceituação do motivo humano da necessidade de teorizar, lembrando que teorias existem para nos ajudar a contemplar o mundo. Algumas teorias são empíricas, outras metafóricas, algumas são de níveis mais generalizados e outras de níveis mais específicos. Assim, o autor entra na discussão dos seus principais objetivos com a sua obra, eles são tanto meta-teóricos como teóricos. O primeiro pensa nas teorias da tradução de um ponto de vista histórico e sugere uma estrutura de visões díspares que a tradução pode ser associada e o segundo sugerindo uma visão teórica da tradução influenciada por Karl Poppers (1992), pela teoria normativa e teoria de ações dentro de um conceito de normas, estratégias e valores para uma teoria tentativa considerando a eliminação do erro e a evolução do conhecimento obj etivo.

\footnotetext{
* Estudante de doutorado do Programa de Pós-Graduação em Estudos da Tradução da Universidade Federal de Santa Catarina
} 
PfAU, M. - Resenha: Memes of Translation: The spread of ideas in translation theory

0 autor abre a seu discurso afirmando que muitos tradutores desconfiam de teorias de tradução, ou mesmo acreditam que não possa existir uma teoria para traduzir. Contrário a essa posição, Chesterman acredita que todo tradutor deve ter uma teoria de tradução, porque sem teoria, ele estará traduzindo às cegas. Assim, ele divide sua obra em sete capítulos tentando abordar um amplo conceito sobre os caminhos da tradução.

No primeiro capítulo, o autor define aquilo que ele chama de memes através de uma apropriação da sociobiologia. Fazendo uma analogia ao termo "gene", o autor explica que um meme é uma ideia que se espalha e se replica tal como os genes na reprodução, descrevendo assim a evolução de um fenômeno cultural que está sujeito aos mesmos tipos de leis. Seria como o darwinismo para a seleção natural dos genes. De acordo com o autor:

\begin{abstract}
“(...) a forma como as ideias se espalham e mudam conforme são traduzidas é como uma evolução biológica que envolve mutações. Assim, o tradutor não é alguém cuja tarefa é conservar algo, mas propagar, espalhar e desenvolver: tradutores são agentes de mudança." ${ }^{1}$ (CHESTERMAN 1997: 2)
\end{abstract}

Meme é uma unidade de transmissão cultural, uma unidade de imitação que se propaga metaforicamente. Assim como os genes, em um conjunto genético (pool), saltam de corpo em corpo através do esperma ou do óvulo, os memes saltam de cérebro em cérebro através da imitação. Ou seja, alguém ouve e passa, e se a ideia for aceita por um grupo maior, ela pode se propagar por si só. As ideias não existem necessariamente em uma forma idêntica, mas possuem similaridades, um denominador comum, um meme. É uma entidade capaz de ser transmitida de um cérebro para outro, como a moda do jeans que Chesterman oferece como exemplo, uma "boa ideia" que se espalha como um gene.

\footnotetext{
${ }^{1}$ Tradução minha. "(...) a translator is not someone whose task is to conserve something but to propagate something, to spread and develop it; translators are agents of change."
} 
PfAU, M. - Resenha: Memes of Translation: The spread of ideas in translation theory

Ideias e convenções que sobrevivem muitas gerações e são eficientemente transmitidas de uma cultura para outra provam assim serem interessantes e relevantes para um grande círculo de seres humanos ${ }^{2}$. (CHESTERMAN 1997: p. 7)

Chesterman divide o conceito de memes em tradução em cinco supermemes, ou seja, em "crenças" coletivas a respeito da tradução: 1metáfora do texto-fonte/texto-alvo, ou seja, a ideia de que a tradução é direcional e vai de um lugar para outro porque, segundo o autor, as traduções não eliminam os textos originais, ou seja, os memes se replicam em uma metáfora genética de propagação, difusão, extensão e até evolução; 2- Ideia de equivalência, apesar de constatar ser um supermeme em declínio, é a ideia de que um texto equivale ao original a partir de conceitos diferentes abordados por autores diferentes como NIDA (1964), J AKOBSON (1994), NEWMARK (1981), HOUSE (1981) e NORD (1991) a respeito da preocupação da igualdade; 3- O mito da intraduzibilidade, pela razão de não ser possível uma equivalência universal em forma e conteúdo, a ideia de que traduzir é impossível, de que o "todo" não é traduzível; 4- 0 argumento livre/literal, considerando que as traduções são realizadas na impossibilidade de uma equivalência perfeita da forma original e de que a tradução livre pode não ser considerada uma tradução, mas somente uma imitação ou adaptação; e, 5- A idéia de que toda escrita é um tipo de tradução; retirando, assim a ideia do intraduzível já que as palavras não pertencem a um único indivíduo, pois foram utilizadas anteriormente.

No segundo capítulo, Chesterman traz uma discussão histórica que ele chama de evolução da tradução ocidental, em estágios acumulativos considerando o ato de refletir sobre a tradução como uma prática milenar. Ele também divide essas tendências sobre como pensar a tradução em oito grupos de conceitos e estudo: 1- Palavra, percebendo a tradução como um

\footnotetext{
${ }^{2}$ Ideas and conventions that survive many generations, and are successfully transmitted from one culture to another, thus prove themselves to be interesting and relevant to a wide circle of human beings.
} 
PfAU, M. - Resenha: Memes of Translation: The spread of ideas in translation theory

processo de reconstrução, as palavras são vistas como as primeiras unidades de tradução onde a solução está no uso da mesma palavra-significado para garantir a equivalência; 2- A Palavra de Deus, os pensamentos para a tradução de textos religiosos levando em consideração o risco da blasfêmia e da heresia que passa a aceitar algumas mudanças formais mínimas na tradução para traduzir a "palavra absoluta", pois a ideia do significado passa a se estender ao texto como um todo; 3- Retórica, como nem todos os textos são escrituras sagradas, muitos deles, principalmente no período da Renascença, aceitavam mais interpretações, comentários, adaptações e explicações dando prioridade aos leitores finais e questionando a escravidão do tradutor e percebendo a tradução como uma beneficiadora da língua-alvo para o exercício do discurso natural e vernacular; 4- Logos, essa prática critica tanto a imitação livre como o excesso de literalidade e procura por um equilíbrio considerando o tradutor como formador de cultura; 5- Ciência Linguística, tendência do início do século XX onde a tradução é vista como uma transcodificação matemática objetiva e explícita de um modo científico, a ser realizada por lingüistas; 6Comunicação, que defende a ideia de que o tradutor é um mediador entre 0 autor e o leitor final devendo ser leal a ambos considerando que a eficiência comunicativa está na proposta da tradução, como uma prática que atravessa culturas; 7- Alvo, o texto-fonte perde seu status supremo e o estudo é direcionado para uma abordagem descritiva, na tentativa de entender o que são traduções e não como elas deveriam ser. Aqui também se encontram os polissistemas, uma rede sistemática e linguística que se altera conforme a cultura, o conceito de normas na influência das decisões tradutórias, o póscolonialismo com a representação do Outro e a ideia de manipulação do discurso, da natureza das línguas e dos direitos autorais; e finalmente, 8Cognição, estudo realizado sobre o comportamento do tradutor no processo tradutório, sobre seu pensamento e seu auto-conhecimento. Chesterman vê todos esses memes - e talvez outros - presentes em um conj unto heterogêneo nos dias de hoje, desde os estágios linguísticos, abordagens hermenêuticas e místicas, teorias comunicativas até o realismo psicológico e percebe que 
PfAU, M. - Resenha: Memes of Translation: The spread of ideas in translation theory

muitas vezes há uma alta de concordância entre elas sobre o conceito de uma teoria de tradução. 0 autor também tenta prever o futuro de uma teoria de tradução a partir do estabelecimento de leis que descrevam tendências tradutórias sob dadas condições em uma tentativa empírica das Ciências Sociais através de observações e experimentos além da continuação da exploração de temas sócio-culturais, ideológicos e éticos. 0 próximo passo, segundo o autor, está além da descrição do "o que", mas a explicação do "por quê".

Chesterman discute sobre uma teoria de normas que fornece ferramentas eficientes para pensar na tradução em termos de teoria e prática no terceiro capítulo. As normas surgem a partir dos memes que, de algum modo, se tornam dominante neste conjunto, impostos em uma relação de poder ou inseridos e aceitos por uma determinada comunidade. As normas são realidades sociais conhecidas pelos indivíduos de um grupo social e fazem parte do senso comum. Elas normalmente são reconhecidas por ser um comportamento geral e podem ser do tipo ética, técnica, lingüística, comunicativa e tradutória. A análise descritiva de uma tradução a partir das normas tradutórias permite que a tradução não fique em uma escala inferior; é uma descrição de práticas particulares dentro de uma dada comunidade cujos indivíduos, na sua maioria, compartilham noções sobre aquilo que é "correto". Para trabalhar com o os estudos descritivos de uma tradução, através do teórico Gideon Toury (1980, 1985, 1991), o autor reconhece que uma tradução é considerada como tal ser for aceita na cultura-alvo através de um mínimo de normas exigidas pela cultura, ainda que seja uma tradução "excêntrica". Essa tradução deve vir de um texto-fonte, de um processo de transferência e de uma relação intertextual entre texto-fonte e alvo. Essas traduções, variando entre o que é adequado ou aceitável para a cultura-alvo, cumprem com as expectativas do leitor através de estruturas prevalecentes, como ideologia e relações de poder.

0 quarto capítulo sugere uma mudança de foco do produto para 0 processo a partir de como os tradutores encontram as normas e quais são suas 
PfAU, M. - Resenha: Memes of Translation: The spread of ideas in translation theory

estratégias tradutórias em uma abordagem popperiana. Chesterman afirma que estratégias de tradução também são memes e alguns memes se tornam normas. Estratégias fazem parte do cotidiano dos tradutores já que tradutores são pessoas que se especializam em resolver diferentes tipos de problemas de tradução. As estratégias tradutórias são processos que os tradutores realizam ao procurarem entrar em conformidade com as normas e dependem do conhecimento e das concepções de cada um deles; elas podem ser orientadas pelo objetivo final da tradução, podem estar centradas intuitivamente nos problemas iniciais, podem ser potencialmente conscientes para problemas individuais ou mesmo intersubjetivas. Chesterman faz uma classificação sobre estratégias tradutórias a partir de três eixos principais, nomeando e dando exemplos para cada um: 1 - Estratégias sintáticas: Tradução literal, Empréstimo ou Calque, Transposição, Deslocamento de unidades, Mudanças de estrutura, Mudanças de estrutura de partes de frases em termos constituintes, Mudanças de estrutura de sentença, Mudanças de coesão, Deslocamento de níveis e Mudanças de esquema; 2- Estratégias semânticas: Sinonímia, Antonímia, Hiponímia, Oposição, Mudanças de abstração, Mudanças de distribuição, Mudanças de ênfase, Paráfrase e Mudanças de tropo; 3- Estratégias pragmáticas: Filtro cultural, Mudança de Explicitação, Informação, Mudanças interpessoais, Mudanças de elocução, Mudanças de coerência, Tradução parcial, Mudanças de visibilidade e Reedição ou Reescrita total. 0 autor também considera a motivação do tradutor em entrar em conformidade com as normas pré-estabelecidas dentro dos limites da significância e da compensação.

o quinto capítulo entra na tentativa da construção de uma teoria de tradução a partir do reconhecimento de erros - considerando o erro como uma fal ha em cumprir com a expectativa do ponto de vista da proposta normativa, da intenção do receptor. Chesterman discursa sobre como avaliar as tentativas de entrar em conformidade com as normas em um senso descritivo e também prescritivo a partir do ato tradutório e de análises críticas de tradução. 0 autor sugere cinco tipos de avaliações de traduções: 1- Avaliação 
PfAU, M. - Resenha: Memes of Translation: The spread of ideas in translation theory

retrospectiva, onde há normas de relação entre o texto-fonte e texto-alvo observando se a expectativa está em conformidade a partir de uma abordagem descritiva; 2- Avaliação prospectiva, considera que o texto-fonte nem sempre é acessível para uma relação, esta análise trabalha com normas de comunicação do ponto de vista da intenção e do motivo de uma tradução existir; 3- Avaliação lateral, trabal ha com a norma da expectativa dos leitores a partir da relação deles com textos autênticos do mesmo tipo, chamados textos paralelos, que já existem na cultura-alvo; 4- Avaliação introspectiva, analisa o processo interno de tomada de decisão do tradutor a partir das normas de responsabilidade, em uma abordagem que pode tanto ser descritiva como prescritiva; 5- Avaliação pedagógica, inclui todas as normas já mencionadas e acontece através da capacitação do tradutor por outro tradutor ou por um professor em uma abordagem prescritiva onde 0 avaliador, a partir de suas próprias competências, analisa a tradução considerando os erros que, segundo o autor, são relativos e nunca absolutos.

Em uma abordagem prática e pedagógica, Chesterman percebe a implicação da teoria popperiana de tradução no sexto capítulo, entre a relação da teoria e o tradutor. Ele divide a experiência tradutória em etapas de aprendizagem. 0 primeiro passo do aprendiz, que ele chama de "novato", é o reconhecimento das tarefas de um tradutor, as regras e o reconhecimento de suas características para a manipulação dos textos. Em um segundo momento onde o aprendiz é um "iniciante avançado", ele já consegue reconhecer muitas características situacionais e assimilá-las a situações previamente trabalhadas. Logo, ele atinge o nível de "competência" e desenvolve um senso de prioridades, um processo hierárquico de tomada de decisão, um plano de ação e uma experiência baseada na compreensão intuitiva e ação deliberativa para a resolução de seus problemas. 0 próximo passo é quando o tradutor fica "proficiente" e suas decisões são baseadas nas experiências individuais de um conhecimento adquirido. Finalmente, 0 tradutor atinge o nível da "especialista" com competência para realizar 0 processo de auto-reflexão, de decisão racional calculada, com um 
PfAU, M. - Resenha: Memes of Translation: The spread of ideas in translation theory

desempenho fluído e controle da situação. Segundo o autor, as tarefas de tradução variam naquilo que requer racionalidade deliberativa e intuitiva, dependendo, logicamente, do tipo de texto que se está trabalhando. Ainda neste capítulo, Chesterman sugere abordagens de ensino de tradução para formar um profissional: exercícios com estratégias, onde o aprendiz analisa um texto original e sua respectiva tradução observando as estratégias tradutórias apontadas no capítulo 4, procura compreender o uso delas e é encorajado a inventar suas próprias estratégias. 0 aprendiz também pode fazer exercícios de responsabilidade ética, como um resumo e tradução de um texto ao mesmo tempo percebendo as prioridades que ele quer manter, ou escrevendo um texto livre e trocando com um colega que irá traduzi-lo, possibilitando, assim, um exercício reflexivo sobre o seu próprio texto. Também podem ser realizados exercícios na norma da comunicação, como práticas de redação nas línguas de proficiência do aprendiz para se familiarizar com a escrita e comunicação, exercícios na norma da relação, para que 0 aprendiz amplie seus conceitos sobre as relações entre texto-fonte e texto-alvo e compreenda a variedade de relações existentes no processo de tradução e exercícios na norma da expectativa, onde o aprendiz fará um estudo com textos paralelos.

Finalmente, em uma abordagem conclusiva, o sétimo capítulo trata a respeito de valores éticos sob as normas que governam a ação tradutória. Em um primeiro momento, Chesterman relembra discussões éticas recentes de teóricos da tradução como BeRMAn, VENUTI e PYM sobre assuntos que tangem a visibilidade do Outro em obras traduzidas, direitos autorais, visibilidade do tradutor e definição da disciplina de Estudos da Tradução. Logo, o autor questiona a ação do tradutor ao entrar em conformidade com as normas na tradução percebendo as normas como promotoras de alguns valores, como ideias reguladoras. Estas são o sujeito de uma análise ética, pois o autor afirma que as normas pelas quais os tradutores entram em conformidade são aquelas que os obrigam a um determinado tipo de comportamento aceitável no meio. Assim, o autor evidencia os quatro valores de tradução que Ihe 
PfAU, M. - Resenha: Memes of Translation: The spread of ideas in translation theory

parecem fundamentais, de um modo descritivo: 1- Claridade, como uma comunicação racional em valor linguístico, de modo que o que queira ser dito seja compreensível; 2- Verdade, entre as relações de existência com o textofonte e outros textos constituintes, de modo a estar em conformidade com uma ou algumas das verdades do outro texto; 3- Confiança, o tradutor confia em um texto que acredita que sua tradução val ha a pena por qualquer razão que seja, e também confia no autor do texto-original e nos seus leitores que lerão o texto de boa-fé em um acordo mútuo de confiança com o tradutor; e 4- Compreensão, pensando no sentido comunicativo, o processo entre aquele que comunica e aquele que é comunicado, as intenções e as expectativas e 0 valor da compreensão. Chesterman encerra sua obra discursando brevemente sobre uma tendência de tradução existente entre alguns grupos de teóricos que ele chama de "tradução emancipatória", onde uma crítica tradutória possibilita que o tradutor seja um membro genuinamente participativo de modo responsável dentro do ponto de vista ético podendo assumir certos poderes e direitos sobre o texto.

Apesar de o autor assumir o risco de tentar escrever uma teoria unificadora e ousada tentando se aproximar de métodos mais empíricos para assuntos que ele mesmo viu como subjetivos ao longo da história da teoria da tradução, Chesterman consegue trazer à tona o que vem se falando neste assunto de modo didático e conciso e não parece desaproveitar nada do que foi dito, porque através dos memes, é possível perceber que todas as tendências que existem e existiram sobre tradução, estão apropriadas dentro do contexto do discurso em que são utilizadas. Chesterman, utilizando todo o apanhado histórico que ele levanta detalhadamente na sua obra, propõe ir mais além do que já foi feito, encoraj ando pesquisadores em questionar mais o processo não só de um modo descritivo, mas também prescritivo dependendo da situação. No mínimo, sua teoria tentativa de tradução suscita à reflexão. 